\title{
Satisfaction attributes related to safety and quality perceived in the experience of hospitalized patients
}

\author{
Atributos de satisfação relacionados à segurança e qualidade \\ percebidos na experiência do paciente hospitalizado \\ Atributos de satisfacción relacionados a la seguridad y cualidad \\ percibidos em la experiencia del paciente hospitalizado
}

\author{
Diovane Ghignatti da Costa ${ }^{a}$ \\ Gisela Maria Schebella Souto de Mourab \\ Mariana Goes Moraes ${ }^{c}$ \\ José Luís Guedes dos Santos ${ }^{d}$ \\ Ana Maria Müller de Magalhães ${ }^{\mathrm{e} f}$
}

How to cite this article:

Costa DG, Moura GMSS, Moraes

MG, Santos JLG, Magalhães AMM

Satisfaction attributes related to safety

and quality perceived in the experience

of hospitalized patients. Rev Gaúcha

Enferm. 2020;41(esp):e20190152.

doi: https://doi.org/10.1590/1983-

1447.2020.20190152 a Universidade Federal de Santa Catarina (UFSC), Centro de Ciências da Saúde, Departamento de Enfermagem. Florianópolis, Santa Catariana, Brasil.

b Universidade Federal do Rio Grande do Sul (UFRGS), Escola de Enfermagem, Departamento de Apoio e Orientação Profissional. Porto Alegre, Rio Grande do Sul, Brasil.

Universidade Federal do Rio Grande do Sul (UFRGS), Escola de Enfermagem. Porto Alegre, Rio Grande do Sul, Brasil.

${ }^{\mathrm{U}}$ Universidade Federal de Santa Catarina (UFSC), Departamento de Enfermagem, Programa de PósGraduação em Enfermagem. Florianópolis, Santa Catariana, Brasil.

Eniversidade Federal do Rio Grande do Sul (UFRGS), Escola de Enfermagem, Programa de Pós-Graduação em Enfermagem. Porto Alegre, Rio Grande do Sul, Brasil.

Hospital de Clínicas de Porto Alegre (HCPA), Grupo de Enfermagem, Gerência de Risco. Porto Alegre, Rio Grande do Sul, Brasil.

\section{ABSTRACT}

Objective: To unveil patient satisfaction attributes related to safety and quality of care.

Methods: Qualitative study carried out in a public university hospital in the south region of Brazil. Data were collected in November 2018 through 24 interviews with patients/families from 12 clinical and surgical hospitalization units. Thematic analysis was carried out.

Results: The satisfaction attributes were categorized in terms of structure, process, and care outcome, and they were related to: access to the service, amount of personnel, environment, interaction with the health team, staff's technical competence, perception of safety with the presence of a relative, assistance patterns present in the care, and change in the health status of the patients.

Conclusions: It was verified that the structural aspects were relevant in the patient's experience, besides the relationship established with the health team in the care process, and the technical assistance standards perceived in the staff's work.

Keywords: Patient satisfaction. Patient safety. Patient participation. Quality of health care. Patient-centered care.

\section{RESUMO}

Objetivo: Desvelar atributos de satisfação dos pacientes relacionados à segurança e qualidade assistencial.

Métodos: Estudo qualitativo, realizado em hospital universitário público do sul do Brasil. Os dados foram coletados em novembro de 2018, por meio de 24 entrevistas com pacientes-famílias de 12 unidades de internação clínicas e cirúrgicas. Procedeu-se à análise temática. Resultados: Os atributos de satisfação foram categorizados em estrutura, processo e resultado assistencial, os quais foram relacionados a: acesso ao serviço, quantitativo de pessoal, ambiente, interação com a equipe de saúde, competência técnica dos profissionais, percepção de segurança com a presença do familiar, padrões assistenciais presentes nos cuidados e mudança no estado de saúde dos pacientes.

Conclusões: Constatou-se que os aspectos estruturais foram relevantes na experiência do paciente, além da relação estabelecida com a equipe de saúde no processo de cuidado e dos padrões técnicos assistenciais percebidos na atuação dos profissionais.

Palavras-chave: Satisfação do paciente. Segurança do paciente. Participação do paciente. Qualidade da assistência à saúde. Assistência centrada no paciente.

\section{RESUMEN}

Objetivo: Develar atributos de satisfacción de los pacientes relacionados a la seguridad y calidad asistencial.

Métodos: Estudio cualitativo, realizado en hospital universitario público del sur de Brasil. Los datos fueron recolectados en noviembre de 2018 por medio de 24 entrevistas con pacientes y familias de 12 unidades de internación clínicas y quirúrgicas. Se procedió al análisis temático.

Resultados: Los atributos de satisfacción fueron categorizados en estructura, proceso y resultado asistencial, los cuales estuvieron relacionados a: acceso al servicio, cantidad del personal, ambiente, interacción con el equipo de salud, competencia técnica de los profesionales, percepción de la seguridad con la presencia del familiar, patrones asistenciales presentes en los cuidados y cambio en el estado de salud de los pacientes.

Conclusiones: Se constató que los aspectos estructurales fueron relevantes en la experiencia del paciente, además de la relación establecida con el equipo de salud en el proceso de cuidado y de los patrones técnicos asistenciales percibidos en la actuación de los profesionales.

Palabras clave: Satisfacción del paciente. Seguridad del paciente. Participación del paciente. Calidad de la atención de salud. Atención dirigida al paciente. 


\section{INTRODUCTION}

Patient experiences are considered increasingly relevant when assessing health services. In such cases, the perspective of those who use the services is co-opted to promote improvements that positively affect patient experiences. The new approach to improving quality with the active participation of patients was essentially based on one of the actions of the World Alliance for Patient Safety established more than a decade ago, from the need to expand means that reduce unnecessary injuries associated with health care $^{(1)}$.

The action called Patients for Patient Safety strengthened the partnership between service providers, patients, and their families by ensuring the voice of patients served as a basis for the patient safety movement ${ }^{(1)}$. In line with this global movement, the National Health Inspection Agency published priority guidelines for patient safety in Brazil that highlight patient involvement as a key element for quality care, considering investments to promote patient safety initiatives with the participation of patients and their families ${ }^{(2)}$.

Interestingly, patient engagement in health care quality assessments is the central nucleus of the Donabedian framework, which systematized service provision assessments based on structure, process, and outcome ${ }^{(3)}$. Quality in health is regarded as a set of attributes related to professional excellence, efficient use of resources, minimal risk to patients, and high patient satisfaction ${ }^{(3)}$. This conceptual basis is closely related to the guidelines established by the World Health Organization to reduce the risks of unnecessary harm associated with health care ${ }^{(1)}$.

Similarly, in the context of health care, patient satisfaction is intrinsically associated with quality assessments and considered part of service marketing, in which the term customer is used to refer to the individual that receives the service. In this sense, the term corresponds to the perception of customers in relation to the service received based on their expectations, scored according to different levels of satisfaction ranging from insufficient, when the service does not meet expectations, to excellent, when the service exceeds initial expectations ${ }^{(4)}$.

In this perspective, the Donabedian triad provides attributes considered concrete in service provision that are easier to measure and related, among other factors, to the environment, resources, and care standards defined by the institution. Moreover, the purpose of this assessment is to reveal underlying factors in care that directly affect quality, namely the technical and interpersonal performance of workers, since the best practices in these domains are thought to produce significant outcomes and improvements in health care $^{(3)}$. Therefore, these attributes directly influence patient satisfaction in relation to the care received and, consequently, to their experience.

Although patient participation in quality health assessments by means of satisfaction surveys is a common practice in several services ${ }^{(5-7)}$, progress regarding patient safety in health services is still slow, especially considering the high incidence of preventable adverse events. A study involving five South American countries, including Brazil, showed that $10.5 \%$ of hospitalized patients suffer some type of adverse event and $58.9 \%$ of these events are considered avoidable ${ }^{(8)}$. Another more recent study conducted in a European country revealed that $10.3 \%$ of inpatients suffered adverse events, of which $72.7 \%$ were avoidable ${ }^{(9)}$.

These findings are more worrying when we consider that patients can help identify weaknesses in care that threaten safety ${ }^{(6)}$; however, their involvement in the improvement of services is poorly explored ${ }^{(10)}$. The perspective of patients in relation to the services offered differs from the perspective of the professionals, indicating the need to explore care experiences and seek contributions to improve patient safety and, therefore, the patient experience based on those who receive care ${ }^{(6)}$.

Global and national recommendations based on initiatives to promote patient safety and patient involvement in safety actions, associated with the gaps in the literature on the theme, resulted in the following research question: Do satisfaction attributes related to patient safety emerge in the experience of inpatients? Consequently, the aim of this paper was to reveal the attributes of patient satisfaction related to the safety and quality of care.

\section{METHODS}

This study is based on exploratory- descriptive and qualitative research, which unveils the individual or collective meanings of the studied phenomenon ${ }^{(11)}$, thus agreeing with the investigated object because it involves the perceptions and interpretations of the subjects involved. This article originated from the doctoral thesis titled "A experiência do paciente na coprodução de cuidados: percepções acerca da qualidade no serviço hospitalar", linked to the Programa de Pós-Graduação em Enfermagem da Universidade Federal do Rio Grande do Sul.

The research scenario was a public university hospital in southern Brazil that received quality accreditation from the Joint Commission International. The participants were 22 inpatients and eight adult family members in 12 clinical and surgical units. The number of participants was 
intentionally determined based on the interview plan of two patients-family members per unit, totaling 24 interviewees. Six patients participated in the interviews with their family members and one interview was conducted for each patient-family member pair. In two interviews, only the family members participated, considering the patient's characteristics, while in 16 interviews, only the patients participated. Data saturation was used to determine when enough interviews had been conducted, recorded according to repeatability.

The inclusion criteria for the patients were individuals who had been admitted for six days or more, interest in sharing their experience, and the ability to move to a private interview room at the hospital unit. In relation to the families of the patients, the inclusion criteria were interested in reporting their perceptions and to be the family member of reference during hospitalization, that is, individuals who had accompanied the patient for more than half the hospital stay period. These criteria were defined considering the participation of the family member in the patient's care experience. The unit census lists were used to invite the patients and their family members because they contain the names and admission dates of patients. The first male patient and the first female patient of each unit were selected. The exclusion criterion was any impediment to communication, which would prevent participants from describing their perceptions.

Data were collected through interviews with a semi-structured script that guided the investigation of the experiences of patients-family members in relation to the investigated object, conducted in November 2018 by the main researcher. The instrument was elaborated according to the Critical Incident Technique ${ }^{(12)}$, used to explore and describe the observations of interviewees on significant situations in relation to the investigated object. In conducting the interviews, the critical incident was considered to be the perceptions that made up the memories of patients regarding quality and safety, in which it was possible to co-opt a situation, the present behaviors, and their consequences, both positive and negative, analyzed in the patient's experience during the hospital stay. After the initial assertion, the time required for the patients-family members to retrieve a significant situation from memory was respected. Then, the dialogue between interviewer and participant was guided by means of a question script, as shown in the following examples: What situation did you remember? Who was involved? What did you perceive in the behaviors of those involved, including yours? Why did you choose to report this event? What could have been different?
The interviews lasted between 30 and 40 minutes. They were recorded, literally transcribed, and subjected to thematic analysis using Nvivo 11 software to organize the thematic corpus ${ }^{(11)}$. Next, the emerging themes were identified and grouped into categories according to pre-analysis, exploration of the material, treatment of the results obtained and interpretation based on the Donabedian framework - structure, process, and outcome ${ }^{(3)}$.

The ethical precepts were observed and research was approved under the CAEE number 01092918.2.0000.5327, based on the documents for consent: term for the use of institutional data and informed consent statement for the patients and their family members. For the presentation of results, the interviewee's statements were coded using the letter $\mathrm{P}$ for patients, $\mathrm{F}$ for family member, and number of the chronological order of the interviews.

\section{口 RESULTS}

Initially, the characterization of the patients who participated in the research is presented, followed by the findings.

The median age was 57 years, with a minimum age of 34 years and a maximum of 75 years. There was parity in relation to gender, predicted in the planning, according to the inclusion criteria. The median length of hospitalization was 14 days, with a minimum of six days and a maximum of 52 days. Regarding schooling, most of the participants had finished elementary school (9) and high school (9), followed by participants who had higher education (5) and illiterate participants (1). The reasons for hospitalization were related to clinical and surgical comorbidities, both acute and chronic.

The themes that emerged from the experiences of the patients-family members related to quality and patient safety characterize attributes for the perception of patient satisfaction in relation to the care received. Chart 1 shows a summary of these results, categorized according to the Donabedian framework.

Patients access the studied hospital, in the case of non-elective care, through the emergency unit, which, according to the statements of the participants, is constantly overcrowding. Among the structural aspects, in addition to the unsupportive environment for the care demand, some patients reported experiences that showed accessibility to the service emerge as an important attribute of satisfaction:

[...] once I got here and I couldn't even get in, because of overcrowding, they explained [...], I didn't insist much, they said to come back next week. I came back and managed to get attended. (P3) 


\begin{tabular}{|c|c|}
\hline Theme & Subthemes \\
\hline \multirow{6}{*}{$\begin{array}{l}\text { Structural } \\
\text { aspects }\end{array}$} & Accessibility to the service \\
\hline & Therapeutic or intimidating environment \\
\hline & Number of staff members \\
\hline & Available resources for treatment \\
\hline & $\begin{array}{l}\text { Conditions for family members to } \\
\text { accompany the patient }\end{array}$ \\
\hline & Transport between sectors \\
\hline \multirow{4}{*}{ Care process } & Interaction with the health team \\
\hline & Technical competence of professionals \\
\hline & Care standards adopted in care \\
\hline & $\begin{array}{l}\text { Presence of the family member } \\
\text { during hospitalization }\end{array}$ \\
\hline \multirow{2}{*}{$\begin{array}{l}\text { Capacity } \\
\text { to solve } \\
\text { problems }\end{array}$} & Performance of workers \\
\hline & Change in the patient's health status \\
\hline
\end{tabular}

Chart 1 - Synthesis of the research results. Porto Alegre, RS, Brazil, 2018.

[...] what I thought was tough was that I needed to come to the hospital at night, I was feeling bad, but the emergency service does not attend though medical insurance, only through the Unified Health System. I agreed to stay there because I had no other solution, but this could be different, I had a bed up here, but they don't admit through medical insurance because of the shortage of physicians. (P20)

Regarding the environment, after accessing the service, the participants mentioned the efforts to accommodate their care needs.

[...] it is very complicated to be with so many people [in the emergency service] because we see a lot of depressing things, not the most pleasant environment to be in, but it is a necessary evil. (P2)

[...] down there [emergency service] we are well treated, the problem is that there are lots of people, we get dizzy. (P21)
Some participants also mentioned the circulation of people as an issue that interferes with patient safety.

[...] a lot of the doors here in the hospital only open with the nurses' badge, so some people rush in to pass with them and if someone notices that the person does not have a badge, no one asks if it is you. (P8)

[...] if you know the entrances here at the hospital, it's easy to wait around and tag along with someone when they go in. Being alert to this is security. (F8)

The participants described characteristics that are part of a therapeutic environment and characteristics that represent an intimidating environment:

[...] here it is comfortable, here we feel welcome, without all the noise [from the emergency service]. (P15)

[...] it seems that I am a guest here because they are all very attentive. (P5)

[...] the environment here intimidates us [...] because we see other people's suffering, but that is how it is in a public hospital, everything is a learning experience. (P23)

Continuing with the satisfaction attributes related to structure, the patients-family members stated the insufficient number of staff members for the care demands:

[...] we see there is a shortage of employees, but the health situation [pause], it is like that everywhere, a lot of people to attend and few workers. (P3)

[...] we know that the delay to attend is because they are busy, there are not enough people to attend everything that is needed [referring to nursing]. (F13)

The patients-family members mentioned other resources needed for treatment as a factor that is related to the structure, such as medications or specific supplies.

[...] I am taking two kinds of antibiotics, the hospital did not have one of them, but the hospital bought it, I thought that was good, because they are last generation drugs. (P8) [...] here, at the hospital, I notice they have the materials needed for safety, they explained it to me and I use them [precautions for multidrug-resistant germs]. (F14)

The structure available for family members to accompany patients interferes with satisfaction, as stated below. 
[...] downstairs [emergency service] I only had a seat to sit in, here I have this bed to lie on, there it is tougher to get things done [...]. (P3)

[...] the medical insurance does not cover meals, I only get breakfast and I cannot leave her side to get food, either, no way. With the Unified Health System, the person who accompanies the disabled patient gets all the meals. (F9)

Another condition that deserved attention mentioned by the participants was the structure for transporting patients between the sectors.

[...] when I am ready in dialysis and they call someone from here to pick me up, sometimes it takes a long time, [...] because the technician needs to drop what he is doing to pick me up. (P8)

In addition to the structure, the research participants reported satisfaction attributes in relation to the care process, namely their remarkable interaction with the health team. This perception involved professionals who have more contact with the patients-family members, such as physicians, nurses, and nursing technicians. Responsiveness, guidance, and information were some of the highlighted items, as shown in the examples below.

[...], but the staff at the hospital, all of them, take the time to explain what is being done, ask if you agree, give guidelines. (P1)

[...] The information I got at the emergency room was from the nurses, because doctors do not make it very clear, what is happening, although they are considerate [...]. This causes a lot of anxiety, people get annoyed because of that, they complain a lot, precisely because they are misinformed. (P5)

The relationship of trust and empathy and the attentiveness of the health workers were items the participants valued in this theme.

[...] I saw here that everyone wants what is best for me, there are no enemies, so I follow the guidelines they give me, because I trust them. (P2)

[...] at the green [emergency service], I was tired, stressed, and I talked to one of the nurses and she said, "I know, in fact, I do not know what you guys are going through, but we empathize with you because I have never been through this, but we're doing the most we can". (P5)

[...] I learned to deal with the differences in people, there are nurses who walk into the room and do not talk much, and others who make the environment more relaxed, it even strengthens us. (P24)

Another point highlighted by the participants is related to the safety protocols instituted in the care process of the studied field. These protocols were valued by the participants when they were attended, thus forming attributes of satisfaction in terms of safety. In this empirical category, in the theme related to the care process, technical competence emerged, reflected in the standards of the care process.

[...] I am treated well here at the hospital, the service is special, medication right away, pressure right away, everything right away. (P1)

[...] at dialysis, they are as careful as here, so we feel safe, because no matter where you are, the point is that everyone is still the same. (P8)

[...] the explanations I got about how surgery would be and later in the recovery room, everything happened as they said, that is amazing, their competence. (E23)

[...] I had surgery, one thing that was important to me was their competence so I would not feel pain, I felt it anyway, but I knew it was being dealt with, they did what they could to not make it worse, it reassured me. I saw that this is important for them also [team] [...], because they always ask about my pain. (E24).

Concluding the perceptions reported by the participants in relation to the care process, the presence of a family member during the hospital stay was considered a factor that favors the safety and well-being of patients. The following statements illustrate this meaning:

[...] the good thing is that I can be with him, because he does not see well and with that leg as it is, he cannot be alone. I'm here for that, for him to be OK. (F3)

$[. .$.$] one more thing I remember, is that I feel better with my$ familiar around, that's very important. When he leaves for a while, I immediately start wondering what I can do to distract myself. (P13)

[...] in her case, it is better to stick around, because when we are here, she knows where she is, she feels reassured. When she was alone, she was confused, she forgot she was hospitalized. (F22)

The quality of the services, with the capacity to solve problems, perceived by the actions of the health workers and the change in health status, also emerged as an attribute of safety satisfaction for the patients-family members: 
[...] I've been here for over 50 days, I hope now with the surgery that they find the focus of the bacterium, because I've even had endocarditis, so I can go home because it's getting tough. (P8)

[...] Today I'm fine, but after the surgery they detected that I had a problem, they needed to open me up again, redo the surgery. Their competence [physicians] was amazing. They said it was urgent, but they didn't scare me. Like the first time, I went calmly. (P19)

\section{DISCUSSION}

The results reveal, based on the patients' experience, the complexity of the hospital health service, manifested according to their contact with the components of the care assessment triad: structure, process, and outcome ${ }^{(3)}$. In relation to structure, the focus of their perceptions was access to the service, mainly in relation to difficulties caused by overcrowding at the emergency service, when hospitalization depends on this flow of care. According to the Donabedian framework, access and accessibility have similar meanings and refer to the ability to access health services, when necessary, in an easy and convenient way ${ }^{(13)}$. Accessibility or access is one of the factors of service provision related to the capacity to produce services and respond to the health needs of a given population.

With regard to environment, some statements characterize a therapeutic context, in the sense of controlling the circulation of people, reducing noise, offering care conditions to meet the special needs of patients, and providing receptive assistance and comfort. Furthermore, the manifestations included characteristics of the environment when it becomes intimidating, mainly due to the shared experiences of suffering when there is not enough privacy. In terms of structure, the patients-family members perceived that the number of staff members affects care, both when it occurs within the expected time and when it is delayed, and failed to meet their expectations. The conditions provided to the family members to accompany patients were also highlighted, whereby they are provided with means to rest close to the patient and, in some cases, meals.

The satisfaction attributes for structure mentioned by the participants are similar to those recorded in a study conducted in 33 Brazilian municipalities, in which ease of access and the capacity for health workers to solve problems and be attentive were considered highly satisfactory ${ }^{(14)}$. Moreover, the results are similar to those of other studies, in which factors related to structure and access to services are thought to interfere with satisfaction, according to the patients ${ }^{(6-7)}$

For environment, research reveals that the hospital is usually unknown to patients and may be perceived as harsh, with unknown people and procedures and different sounds, lighting, and routines, all of which aggravate their perception and hinder wellness ${ }^{(15)}$. This same study also revealed that patients and their families can be apprehensive about requesting care when the health workers are insensitive to their needs. Another study mentioned factors related to the environment and patient satisfaction, such as noise caused by the team, other patients, and equipment, and in relation to excessive lighting at night ${ }^{(6)}$.

The number of staff members available for care involves the fulfillment of health needs in a timely manner. Regarding the relationship between nursing staff sizing and patient satisfaction, evidence demonstrated that the greater the workload, i.e. the number of patients for each nurse and nursing technician, the greater the average stay of patients and the occurrence of urinary tract infection related to invasive procedures and the lower the satisfaction rate regarding nursing car ${ }^{(16)}$. Similarly, a significant correlation was found between the workload of the nursing team and patient satisfaction ${ }^{(5)}$.

Another striking component in the patients' experience, regarding the Donabedian triad for assessing health quality, concerns the care process, which revealed safety satisfaction attributes related to interactions with the health team that has more contact with patients, such as physicians, nurses, and nursing technicians. The responsiveness, attentiveness, and guidelines they received, as well as the relationship of trust and empathy of the professionals, were valued in their manifestations. In addition, the care process produced attributes of satisfaction that refer to the safety protocols adopted by the hospital, linked to the technical competence of professionals and reflected in the care standards observed to meet their needs. The patients-family members perceived that these care standards have institutional definitions.

Some studies demonstrate how these attributes affect patient satisfaction. A positive correlation was found between patient satisfaction and participation in care $^{(5)}$. In a workload analysis, this study revealed that the hours nurses dedicated to their work did not meet the needs of communication and the information patients received was insufficient, indicating a low level of patient satisfaction in relation to the communication and participation attributes in the care. According to another study, patient satisfaction decreased as nursing care failed to occur in a timely 
manner, which is associated with the lack of nursing staff and a precarious hospital environment ${ }^{(17)}$.

Regarding the care process, the presence of family members was mentioned as important following hospitalization because it favors the well-being and safety of patients. Regarding this perception, a study concluded that the family members who accompany inpatients learn about care, such as prevention of infection and the safe use of supplies and medication, among other procedures, as well as how to interact assertively with the nursing team ${ }^{(18)}$.

This knowledge places family members as an integral and important part of the care process in the hospital environment. In addition to paying attention to the issues that involve patient s safety, they tend to the patient's needs and help create an emotionally supportive environment. According to a study, the need to establish a partnership with patients and family members and, consequently, improve patient safety, increased due to the complexity of health care ${ }^{(15)}$. Moreover, results showed that families know the history of patients, so they are able to provide information that helps the health team understand the patient's perspective, reinforce the treatment plan, notify changes in health status, and offer comfort to the patient. In contrast, the same study revealed that when the desires of the family are not the same as the desires of the patient, the health team must skillfully intervene to verify and manage the situation ${ }^{(15)}$.

Service quality during admission, from the standpoint of results, achieved with treatment, is the last theme that emerged regarding the safety satisfaction attributes in the experience of the research participants. The capacity to solve problems was perceived through the work of the professionals and changes in the health status of patients, and it was directly related to the attributes described in the care process.

According to a study on indicators based on care quality assessments using the Donabedian model, the outcome component of the triad is intrinsically related to the others, which are process and structure ${ }^{(19)}$. The outcome dimension, from the perspective of patients, is observed when expectations related to structure and processes are met, in the sense of offering the necessary resources quantitatively and qualitatively to ensure comfort and safety with defined care processes through the establishment of flow, responsibilities, and specific competencies for each care situation.

In a study that elicited quality care characteristics used to define patient preferences in a health care service, direct contact with the health team was highlighted as the most important attribute when assessing health conditions, such as the physical exam ${ }^{(20)}$. The other attributes were related to access to hospitalization, cleaning conditions, and preparation for hospital discharge. A high-quality service must also organize its work process and train the teams so they dedicate some of their time to interacting with patients during assessments, answering questions, and explaining the treatment plan.

One study analyzed patient perceptions in relation to the quality of health services in the dimensions environment, responsiveness, communication, privacy, and security ${ }^{(7)}$. The findings show a positive correlation between all the variables of patient satisfaction, which was identified as an outcome variable capable of measuring the overall quality of the service.

Moreover, the experience of inpatients reveals attributes of satisfaction related to safety and quality with specific indications regarding their perception of the care received. The safety and quality of care is a constant agenda in several health services. The results of this study and the findings of the literature show that patients-family members pay attention to several factors related to the provision of health care based on attributes of structure, processes, and outcomes of care.

\section{q FINAL CONSIDERATIONS}

The study identified satisfaction attributes related to safety and quality that emerged from the experience of inpatients. The structural aspects were relevant in their perceptions and focused on the accessibility to the service, the characteristics of the environment, the number of staff members available for care, and the conditions for the family members to accompany patients. Regarding the care process, the patients-family members mentioned attributes that refer to the relationship established with the team and the perception of the adopted care standards converging toward their safety. Another striking attribute in patient satisfaction is the presence of the family during hospitalization, which contributed to their perception of safety and quality. The capacity to solve problems of the service is perceived in the performance of workers and in changes to the patient's health status.

One of the limitations of this study was the use of interviews since they may not have fully registered the complete experience during hospitalization. Also, the possible fear of the participants manifested their perceptions about the services offered and provided by the teams, while they depended on their care. This data collection strategy, however, was fundamental to ensure the participation of patients and their family members. The Critical Incident Technique was a powerful strategy to search for the most 
noteworthy facts of the hospital care experience in the memories of the patients-family members.

In relation to future studies, the results refer to the increased participation of patients in their safety since they identified attributes of satisfaction related to safety and quality based on their experience, suggesting the possibility of more research and investment on this action.

The study contributes to the practice and management of nursing and health care by revealing relevant factors for patient engagement in care quality assessment and by emphasizing their role as active agents for the promotion of safe practices, thus unveiling a promising theme for research and a challenging subject for hospital service management. The search for strategies that stimulate patient participation in safe care should encourage health workers to build a new and collaborative partnership with patients.

\section{REFERENCES}

1. World Health Organization (CH). World Alliance for Patient Safety. Forward Programme 2008-2009. Geneva: WHO; 2008 [cited 2019 Apr 20]. Avallable from: http://www.who.int/patientsafety/information_centre/reports/ Alliance_Forward_Programme_2008.pdf

2. Ministério da Saúde (BR), Fundação Oswaldo Cruz, Agência Nacional de Vigilância Sanitária.. Documento de referência para o Programa Nacional de Segurança do Paciente. Braślia, DF: Ministério da Saúde; 2014 [cited 2019 Apr 20]. Available from: http://bvsms.saude.gov.br/bvs/publicacoes/documento_ referencia_programa_nacional_seguranca.pdf

3. Donabedian A. The quality of medical care: how can it be assessed? JAMA. 1988;260(12):1743-8. doi: https://doi.org/10.1001/ jama.1988.03410120089033

4. ZeithamI VA, Bitner MJ, Gremler DD. Marketing de serviços: a empresa com foco no cliente. 6. ed. Porto Alegre: AMGH; 2014.

5. Goh ML, Ang ENK, Chan YH, He HG, Vehviläinen-Julkunen K. Patient satisfaction is linked to nursing workload in a Singapore hospital. Clin Nurs Res. 2018;27(6):692-713. doi: https://doi.org/10.1177/1054773817708933

6. O'Hara JK, Reynolds C, Moore S, Armitage G, Sheard L, Marsh C, et al. What can patients tell us about the quality and safety of hospital care? findings from a UK multicentre survey study. BMJ Qual Saf. 2018;27(9):673-82. doi: https://doi. org/10.1136/bmjqs-2017-006974

7. Fatima T, Malick SA, Shabir A. Hospital healthcare service quality, patient satisfaction and loyalty: an investigation in context of private healthcare systems. Int J Qual Reliab Managem. 2018;35(6):1195-214. doi: https://doi. org/10.1108/IJQRM-02-2017-0031

8. Ministerio de Sanidad y Política Social (ES). Estudio Ibeas: prevalencia de efectos adversos en hospitales de Latinoamérica. Madrid: Ministerio de Sanidad y
Política Social; 2010 [citado 2018 agosto 30]. Disponible en: http://new.paho. org/hq/dmdocuments/2010/INFORME\%20GLOBAL\%201BEAS.pdf

9. Rafter N, Hickey A, Conroy RM, Condell S, O'Connor P, Vaughan D, et al. The lrish National Adverse Events Study (INAES): the frequency and nature of adverse events in lrish hospitals - a retrospective record review study. BMJ Qual Saf. 2017;26(2):111-9. doi: https://doi.org/10.1136/bmjgs-2015-004828

10. Liang L, Cako A, Urquhart R, Straus SE, Wodchis WP, Baker GR, et al. Patient engagement in hospital health service planning and improvement: a scoping review. BMJ Open. 2018;8(1):e018263. doi: https://doi.org/10.1136/ bmjopen-2017-018263

11. Minayo MCS. 0 Desafio do conhecimento: pesquisa qualitativa em saúde. 14. ed. São Paulo: Hucitec; 2014.

12. Flanagan JC. A técnica do incidente crítico. Arq Bras Psicol Apl. 1973 [cited 2019 Apr 20];25(2):99-141. Available from: http://bibliotecadigital.fgvv.br/0js/index. php/abpa/article/viewFile/16975/15786

13. Donabedian A. An introduction to quality assurance in health care. 1st ed. New York: Oxford University Press; 2003.

14. Comes Y, Trindade JS, Shimizu HE, Hamann EM, Bargioni F, Ramirez $L$, et al. Evaluation of user satisfaction and service responsiveness in municipalities enrolled in the Mais Médicos (More Doctors) Program. Ciênc Saúde Coletiva. 2016;21(9):2749-59. doi: https://doi.org/10.1590/141381232015219.16202016

15. Schenk EC, Bryant RA, Van Son CR, Odom-Maryon T. Perspectives on patient and family engagement with reduction in harm: the forgotten voice. J Nurs Care Qual. 2019;34(1):73-9. doi: https://doi.org/10.1097/ncq.0000000000000333

16. Magalhães AMM, Costa DG, Riboldi CO, Mergen T, Barbosa AS, Moura GMSS. Association between workload of the nursing staff and patient safety outcomes. Rev Esc Enferm USP. 2017;51:e03255. doi: https://doi.org/10.1590/S1980$220 \times 2016021203255$

17. Aiken LH, Sloane DM, Ball J, Bruyneel L, Rafferty AM, Griffiths P. Patient satisfaction with hospital care and nurses in England: an observational study. BMJ Open. 2018;8:e019189. doi: https://doi.org/10.1136/bmjopen-2017-019189

18. Passos SSS, Henckemaier L, Costa JC, Pereira A, Nitschke RG. Daily care of families in hospital: What about patient safety? Texto Contexto Enferm. 2016;25(4):e2980015. doi: https://doi.org/10.1590/010407072016002980015

19. Zhou H, Bai G, Gao J, Zhou Y, Ma E, Hu L, et al. The development of indicator measure for monitoring the quality of patient-centered care in China's tertiary hospitals. Plos One. 2018;13(10):e0205489. doi: https://doi.org/10.1371/ journal.pone.0205489

20. Bahrampour M, Bahrampour A, Amiresmaili M, Barouni M. Hospital service quality - patient preferences - a discrete choice experiment. Int J Health Care Qual Assur. 2018;31(7):676-83. doi: https://doi.org/10.1108/ IJHCQA-01-2017-0006

Received: 04.29.2019

Approved: 08.27.2019
Diovane Ghignatti da Costai

E-mail: diovane.g.costa@ufsc.br 